\title{
The Turkish encounter with neo-liberalism: economics and politics in the 2000/2001 crises
}

\section{Ümit Cizre \& Erinç Yeldan}

To cite this article: Ümit Cizre \& Erinç Yeldan (2005) The Turkish encounter with neo-liberalism: economics and politics in the 2000/2001 crises, Review of International Political Economy, 12:3, 387-408, DOI: 10.1080/09692290500170692

To link to this article: https://doi.org/10.1080/09692290500170692

$$
\text { 曲 Published online: } 10 \text { Feb } 2011 .
$$

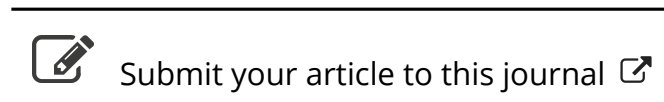

Џlll Article views: 457

4 Citing articles: 30 View citing articles 5




\title{
The Turkish encounter with neo-liberalism: economics and politics in the 2000/2001 crises
}

\author{
Ümit Cizre
}

Bilkent University, Department of Political Science, Ankara

and

\section{Erinç Yeldan}

Bilkent University, Department of Economics, Ankara

\begin{abstract}
Turkey initiated an extensive dis-inflation program in December 1999 backed and supervised by The International Monetary Fund (IMF). The program aimed at decreasing the inflation rate to a single digit by the end of 2002. It exclusively relied on a nominally pegged (anchored) exchange rate system for dis-inflation and on fiscal prudence. In February 2001, however, Turkey experienced a very severe financial crisis, which deepened and continued to-date. The official stance is that the crisis was the result of the failure of the public sector to maintain the austerity targets and the failure to implement fully the free market rationale of globalization. We argue in this article that, contrary to the official wisdom, the current economic and political crisis is not the result of a set of technical errors or administrative mismanagement unique to Turkey, but is the result of a series of pressures emanating from the process of integration with the global capital markets. We further provide a discussion on the fundamental parameters of the Turkish politics connected with the crisis.
\end{abstract}

\section{KEYWORDS}

Economic and political crisis; Turkey; globalization; stabilization; IMF conditionality.

\section{INTRODUCTION}

The last two decades witnessed an extensive shift in the development strategy with the rise to hegemony of the neo-liberal orthodoxy dictating

Review of International Political Economy

ISSN 0969-2290 print/ISSN 1466-4526 online (c) 2005 Taylor \& Francis Group Ltd http:/ / www.tandf.co.uk

DOI: $10.1080 / 09692290500170692$ 
market rationality over any other form of collective decision-making. In the words of Bourdieu (1998), this infernal machine, termed globalization, has sought to destroy all collective structures that are held as a hindrance to the profitability of private capital. Thus, trumpeted with the rhetoric of TINA (There is no alternative) the neo-liberal orthodoxy introduced new rounds of conditionality as part of its hegemonic agenda: privatization, flexible labor markets, financial de-regulation, flexible exchange rate regimes, central bank independence (with inflation targeting), fiscal austerity, and good governance.

This neo-liberal ideology attempted to explain the motives behind financial liberalization arguing that such measures would restore growth and stability by raising savings and improving economic efficiency. Accordingly, as the 'strangulation' of the so-called financial repression is dismantled, loanable funds would expand; the real cost of credit would fall; and the increased pace of capital accumulation would generate sustained growth. A major consequence, however, has been the exposure of those economies that underwent financial deregulation to speculative short-term capital (hot money) attacks, which increased instability and precipitated a series of financial crises. In the last 20 years alone, the world economy experienced about 70 financial crises, with about two-thirds hitting the developing countries (Adelman, 2000).

Furthermore, contrary to expectations, post-liberalization episodes were characterized by the diversion of domestic savings away from fixed capital investments towards speculative financial instruments with often erratic and volatile yields. As a result, developing economies with weak financial structures and shallow markets suffered from increased volatility of output growth, shortsighted investment decisions, and financial crises with severe economic and social consequences. Often the economic crises occurred hand in hand with the ensuing political crises. All of which led to a severe contraction of labor incomes and increased unemployment together with marginalization of the work force, and resulted in violation of basic labor rights in trade union activity, deprivation of rights to engage in collective bargaining and participatory democracy.

Turkey initiated its neo-liberal reforms in 1980 with the liberalization of commodity trade and flexibilization of its labor markets. The capital account was de-regulated and financial liberalization was completed in 1989. After going through a series of short-term cycles of instability-crisis(unsustained) growth-instability throughout the 1990s, Turkey entered a period of severe economic-cum-political crisis in November, 2000 with a final burst of the financial bubble in February, 2001. If the structural market reforms promoted by the then-prime minister Turgut Özal in the 1980s can be termed as Turkey's first-generation economic liberalization, the current stage of neo-liberal economic reform can be termed 'second-generation' marketization reforms. Essentially, both rounds of reforms relied on the 


\section{CIZRE AND YELDAN: THE TURKISH ENCOUNTER}

same prescriptive orthodoxy, namely, the establishment of unfettered freemarket capitalism. However, the new generation of market policies have been formed and implemented in a context where the transnational mobility of capital and global production networks were far more pronounced than before. ${ }^{1}$ Yet as the Turkish economy moved into a new stage of macroeconomic stabilization program, it has become clear that an ill-timed decision on liberalization of capital movements in 1989 had already generated the structural preconditions of the crisis. In this context, the emergence of the February 2001 crisis is directly related to the implementation of the IMF-led adjustment package unveiled in December 1999.

Clearly, the operations of a globalized financial system depend on the existence of connections between the global order and domestic politics. As required, designed and imposed by international financial organizations (IFO's), marketization policies aim to reshape the power relations between the government bureaucracy, national and international capital, and the laboring masses. In fact, the post-February 2001 predicament in Turkey painfully illustrates the theoretical debate on how to modify the statemarket relations in a country to convert it into a reliable and stable partner state in the global capitalist order. The official view is that the February crisis was the result of the failure of the public sector to maintain the austerity targets set by the IMF-led stabilization program initially initiated in December 1999. ${ }^{2}$ Thus, the crisis in Turkey was the result of the failure of the Turkish government to maintain its austerity targets and to implement the necessary structural adjustment reforms on time, thereby disturbing the market agents and causing foreign capital to leave the country.

We argue, however, that the February 2001 political and economic crisis in Turkey was not the product of a few technical errors or mismanagement, but was the result of a set of cumulative processes that were set in motion by the overly premature attempt to liberalize and deregulate the economy. Contrary to the official stance, economic evidence clearly shows that the fiscal targets were reached throughout the implementation of the program in 2000, and the central bank (CB) was successful in maintaining its monetary targets. It is our operating hypothesis in this article, therefore, that because the fragile and shallow domestic asset markets of Turkey's peripheral capitalism were prematurely exposed to foreign competition, and all the underlying conditions for the financial crisis were already in place.

Thus, the question is whether the causes of the crisis and the proposed remedial reforms are as simple and mono-causal as the neo-liberal thinking behind the IMF-backed recovery program in Turkey would lead us to believe. This article addresses these issues based on recent economic evidence. The plan of the article is as follows: in the next section, we offer an overview of the orthodox perceptions on the causes of the February crisis in Turkey. Then we investigate the macroeconomic impacts of financial 


\section{REVIEW OF INTERNATIONAL POLITICAL ECONOMY}

de-regulation in a developing economy in the context of the Turkish experience. We continue with a discussion of the distinguishing characteristics and parameters of the Turkish political apparatus in the aftermath of the crisis. We provide concluding comments in the final section.

\section{ORTHODOX PERCEPTIONS OF THE FEBRUARY 2001 CRASH}

The official interpretation of the causes of the February 2001 crash is based upon what we term the orthodox 'political and economic mismanagement perspective.' That interpretation is further incorporated into the underlying logic of the current structural adjustment program. It argues that the preoccupation with private and political gain in the public bureaucracy and politics compromised the quality of the economic decision-making, which in turn, laid the foundations for the ensuing crisis.

\section{The corruption of public bureaucracy}

Prominently represented by marketization-friendly elements of the political elite -the bureaucracy, media pundits, majority of the academia and the IFO officials - this discourse attributes the 2001 crisis to policy errors and deviations from or deadlocks in the first-generation market reforms. ${ }^{3}$ In a general sense, for this perspective, the blame for the crisis lies in the failure of Turkey to adapt to globalization and seek benefits from it. Accordingly, the failure to implement fully the free-market rationale stems from two clusters of factors that are not mutually exclusive. First, the lack of political will on the part of the government bureaucracy and political actors, second, the fusion of politics with the economics. The combined result, it is argued, was bad governance with wasteful 'populism' and institutional rigidity, which brought about ineffectual and erratic patterns of economic policy-making. ${ }^{4}$ According to this position, the appropriate reform strategy is to make administrative changes that provide the needed disassociation of politics from the economic rationale to manage effectively a market economy.

If we begin by looking at this so-called lack of political will, we can see that those economy bureaucrats and politicians and their supporters in important economic interest groups, which support them contend that the first-generation reform phase and subsequent IMF structural reform programs did not go far enough simply because the political elite lacked the courage to identify themselves with the reforms. ${ }^{5}$ They failed to carry them out and risk the political costs of the kind of austerity measures essential to integrating with global capitalism. The former minister of economy, Kemal Dervis, himself adhered to this point of when he attributed the failure of the past IMF programs to the absence of a group of politicians willing to 


\section{CIZRE AND YELDAN: THE TURKISH ENCOUNTER}

commit themselves to the strong measures required by the structural logic of neo-liberal orthodoxy. ${ }^{6}$ More specifically, for this school of thought, the genesis of the crisis derives from the incompetence of those managing public enterprises: an extensive and expensive series of populist entitlements made possible by the role of the state in the economy. Moreover, it is argued that the character of Turkey's public sector provides the natural habitat for corruption, which in turn precipitated the February 2001 crisis. ${ }^{7}$ It is argued that a large and unprofitable network of state-owned banks has encouraged rent-seeking behavior by bureaucrats and politicians.

\section{Is corruption only public?}

However, there is something amiss in explaining corruption as an aberrant behavior by the public servants only. In the 1990s, an enormous and unsustainable network of some 80 private banks with no connection with the real sector emerged to take advantage of quick returns from public sector debt. They relied on the open and un-regulated financial system for making these quick returns. In fact, as argued forcefully in Cizre-Sakalloglu and Yeldan (2000); Önis and Aysan (2000); and Boratav and Yeldan (2002), throughout 1990s, Turkey's banking and financial institutions became disengaged from financing real production activities to the point where they became the dominant faction within capital and, therefore, able to manipulate the accumulation patterns. Thus, between 1990 and 2000, while the real gross domestic product grew only by $3.4 \%$ per annum, the annual real rate of growth of the banking sector assets exceeded 13\% (Balkan and Yeldan, 2002). This enormous divergence between the performance of the real economy and the financial bubble was clearly a result of the rapid acceleration of short-term foreign capital inflows that were made possible by the lax supervision of a myopic financial sector. Moreover, as marketization intensified, corruption in the private sector also became more commonplace: media barons were seen to be buying banks and siphoning off their assets. $^{8}$

The crucial flaw in orthodox perceptions of public-led corruption and rent seeking is that it tends to view the private sector as a neutral entity, composed of agents and actors obeying only the rationality of the market signals. Yet, as in all peripheral capitalist societies, Turkey's recent economic history shows very clearly how the bourgeoisie itself is a creation of the state; molded, protected and fed by the various rents and positions of advantage that emanate both from distorted production processes and also through state-regulated surplus creation mechanisms. ${ }^{9}$ Thus, the so-called rent seeking activities and the associated waste result not from excessive government intervention, but from the very processes of how private industrial and financial capital seek to appropriate resources to sustain its livelihood. The role of the state in that case is to act where necessary, as 
a non-neutral distributive agent vis-à-vis different segments of the bourgeoisie in order to bring forth the required shifts in the mode of surplus extraction. As Evans (1997, p. 76) argues, perspectives that identify corruption and venality with public bureaucracies and place an emphasis on rent-seeking, do have significant explanatory value, 'If, however, they crowd out all other interpretations of public behavior, leaving public authority as a synonym for rent-seeking and venality, they run the danger of becoming a self-fulfilling prophecy.' When this kind of understanding is combined with the pervasive failure of heavily indebted and politically dependent countries to deliver public goods, the result is a strong antistate and anti-bureaucracy discourse expounded especially by proponents of the neo-liberal consensus.

\section{The fusion of economics with politics}

The second component of the political mismanagement school regards the failure to segregate politics from economics as a primary reason for corruption and lethargy over structural reforms, resulting in the February 2001 crisis. According to Yalman (2002), this anti-state discourse is a form of oppositional hegemonic discourse that has captivated the popular and political mind (Yalman, 2002, pp. 7-9). It portrays the market and civil society as independent realms from the state where freedoms can flourish, while the state is seen as an $a$ historical entity incapable of adjusting itself to global developments, unresponsive to societal changes, and is to blame for bringing about the crisis.

This idea of dissociating market and political forces is a deliberate attempt to disconnect the economic stabilization program from any wider democratization discourse and to break the forces of simultaneity between the two. As a typical representative of this anti-political view, for instance, Mr Kemal Dervis maintained that strengthening the economy by market reforms and establishing a strong democracy in Turkey was a problem of sequence, not a problem of the two issues being tackled simultaneously,

the stronger the economy of Turkey, the more European investment and production come to Turkey, the more trade there is, the more financial links there are, the stronger will be the European interest in integrating Turkey. I do believe that the economy deserves priority. ${ }^{10}$

The problem Kemal Dervis tried to evade by prioritizing economic over democratic reforms is real enough. Genuine democratization is more likely to hinder than facilitate the imposition of this aggressive structural adjustment plan simply because the population seriously hurt by the massive cuts in social spending and layoffs would resist these measures if the process of democratic politics were at work. What is conveniently ignored by this approach is the fact that the separation between market activity and 


\section{CIZRE AND YELDAN: THE TURKISH ENCOUNTER}

political activity is itself a political project. For key economic and social concepts like structural reforms, markets, households, labor, stratification, social networks, poverty, crime and public policies can only be understood through a politics that lends them meaning and stability. Hence, the idea of segregating the political from the economic is subterfuge. Furthermore, the discourse reduces politics to the role of administration and the issuing of technical decrees, and society to a conservative and obedient, and therefore, a malleable mass. Politics is characterized as merely an instrument at the service of markets, efficiency, and profitability. The momentum of the stabilization project is enhanced by subordinating politics to the so-called imperatives of a global agenda. Moreover, by cloaking the IMF-backed stabilization programs in technical and scientific sounding language, the separation discourse smothers the potential for substantive resistance of even a constructive kind. The language of positivistic certitude protects itself because, by definition, it leaves no scope for even the idea of critical thinking.

\section{THE ECONOMIC EVIDENCE}

The Turkish 2000/2001 crises, as in the case of the Argentinean debacle, broke out in the midst of an IMF-directed adjustment program. It became one of the clearest examples of how in a developing economy with shallow and segmented financial markets, the unfettered workings of the myopic markets can serve as the main source of disequilibrium through the speculative attacks of international financial capital flows. In fact, there is now surmountable evidence that with the recent attempts towards full liberalization of the capital account under pressures from the US and the IMF, governments lost their independence in designing a strategic mix of these two instruments for promotion of industrialization/development targets. (See, for example, Adelman and Yeldan, 2000b; Pettifor, 2003; Baker, Epstein and Pollin, 1998.) As open capital markets replaced closed short-term capital markets and regulated flows of foreign investment, governments became unable to employ their traditional policy instruments (interest rates, government expenditures, and exchange rates) unilaterally: Raising interest rates above world markets triggers large inflows of foreign capital, setting the stage for a financial crisis. Fixing them below world markets triggers a large foreign capital outflow, thereby generating a crisis. Similarly, setting exchange rates above equilibrium levels leads to a current account deficit; while fixing them below equilibrium stimulates capital flight and investment abroad, also producing a crisis. Finally, running a budget deficit to stimulate growth or provide social programs more generous than the international norm is also seen to cause capital outflows.

Flexible exchange rates amplify the effects of these international capital flows, by allowing speculation on foreign exchange markets that are 


\section{REVIEW OF INTERNATIONAL POLITICAL ECONOMY}

excessively large; excessively-liquid; excessively volatile; imperfectly informed; and subject to herd psychology. One of the direct impacts of financial de-regulation in Turkey has been the consequent overvaluation of the domestic currency (Turkish Lira-TL). Fueled by excessive inflows of short-term financial capital, the Turkish currency markets became flooded with foreign exchange. As the Lira appreciated and the Turkish tradables lost their competitiveness in the world markets, imports surged and the current account deficit widened, setting the stage for a vicious cycle of growth-instability-crisis.

Resonating the pre-crisis conditions of Mexico 1994, South Asia 1997, and Argentina 2001, the overvaluation of the domestic currency has become a concomitant feature of post-financial de-regulation episodes. In Figure 1, we document this evidence clearly. Here the monthly Turkish Lira/US Dollar exchange rate is portrayed in real terms deflated by the wholesale price index $(1987=100)$ between January 1982 and September 2003. The figure discloses two distinct paths of the real exchange rate: 19821989 and 1989-2003. August 1989, marks the beginning of capital account liberalization and declaration of convertibility of the Lira. The Lira is on a distinctively overvalued plateau after 1989 with two spikes - 1994 and 2001 crises - when a 'corrective' devaluation became imminent. Thus, after financial de-regulation Turkey was already trapped into the conditionalities of international financial system seeking '.... a stable exchange rate (to) underpin the confidence needed for large capital inflows' (Sachs, 1997).

Furthermore, in the 1990's Turkey entered a period of very high real rates of interest with a significant threat of dollarization and capital flight. The specter of capital flight became the main discourse of monetary policy and, as a 'newly emerging market,' Turkey has offered speculative arbitrage rates reaching at times over 100\% during the 1990s. This financial arbitrage can be calculated as the result of an operation that converts initially the foreign exchange into Turkish Liras at the rate $E R$, and after earning the rate of interest $\mathrm{R}$ offered in the domestic asset markets, is re-converted back to the foreign currency at the prevailing foreign exchange rate. Algebraically, this net arbitrage gain is calculated as

$$
\frac{1+R}{1+\varepsilon}-1
$$

Thus, during the course of the operation, financial speculators would gain domestic rate of $R$, and lose at the rate of depreciation of the exchange rate. The net difference between the two prices would give us the net financial arbitrage gain. We calculate the evolution of such gains in Figure 2. Here, the main hypothesis is that the financial arbiters would financially invest their foreign monies at the domestic instrument that would bring the highest rate of return in the domestic asset markets (most of the case 


\section{CIZRE AND YELDAN: THE TURKISH ENCOUNTER}

the government debt instruments - GDIs). According to the calculations portrayed in Figure 2, Turkey offered real rates of 100\% in January 1996; $60 \%$ in December 1998; 80\% in March 2001, and became one of the leading emerging markets in the world of financial speculation.

It would be unrealistic to expect to find fixed investments connected with industrial activities within an economy offering such rates of return in comparison to such speculative financial transactions. As a matter of fact, throughout the 1990s fixed investments linked to the manufacturing industries virtually stagnated and did not exceed their real 1990 levels as of 2001. Consequently, the share of manufacturing investments as a share of total had receded continuously. (The average of 2001 being $22 \%$, in contrast to the 1970s, which averaged $40 \%$.)

Finally, in Figure 3 we portray the movement of net financial flows from the balance of payments data, and contrast it with the growth of real gross domestic product. The figure underscores the observation that under the de-regulated financial environment, sources of growth originated not from domestic capital accumulation, but from the ad hoc and often irrational decrees of foreign (speculative) financial capital. In periods of high inflows of financial capital, growth rate of the gross domestic product tended to increase, yet periods of capital flight meant direct recession - even outright collapse as in 1994, 1999, and 2001.

Under these conditions, whatever the growth performance of the economy during the post-capital account liberalization, it had to be based on speculative-led patterns (á la Grabel, 1995). Consequently, finance was elevated over industry and the real sphere of the economy, and the financial sector drifted to the speculation of the short-term capital flows in a process that has been characterized as casino capitalism (Strange, 1986). Thus, we argue that the crisis conditions emerged, mainly because of the increasing fragility in the financial system. This fragility, in turn, was generated by the uncontrolled and excessively volatile capital flows, which were characterized by a high level of speculation. Turkey had been trapped in this cycle with its premature move towards financial deregulation in 1989, and the opening of its domestic asset markets to international capital flows.

Given this new environment the Turkish Central Bank lost control over its monetary policy instruments. As in all other developing economies that took similar steps towards external liberalization, Turkey was trapped into a vicious cycle of high real interest rates, appreciated Turkish lira, and inflows of speculative short-term foreign capital. ${ }^{11}$ This cycle reached its zenith during the implementation of the 2000 exchange rate-based disinflation program as the currency risk was eliminated and the whole liquidity generation mechanism was based on the short-term, hot money inflows. Increased foreign exchange activity led to the appreciation of the Lira in real terms. Imports surged, exports fell, and the current account deficit widened. This process continued in cycles until the financial 


\section{REVIEW OF INTERNATIONAL POLITICAL ECONOMY}

speculators interpreted the expanding current account deficits as signifying the fragility of the domestic financial system. At this point, capital inflows came to a sudden halt and turned into outflows, leaving the country illiquid and the central bank with no control over its instruments, and therefore, unable to stabilize the economy.

According to Akyüz and Boratav's (2003) calculations, in the last week of November, 2000 alone Turkish financial markets lost $\$ 5.3$ billion via nonresidents' short-term speculative operations. In fact, with this rapid change of direction, net flows of non-residents' foreign capital would turn to $\$ 8.7$ billion after November and the Turkish asset markets' loss of foreign exchange reached $\$ 23.9$ billions. Faced with these numbers, a financially shallow emerging market economy such as Turkey could not endure the disruptive consequences of such financial shocks. Yet, the 2000 dis-inflation program completely ignored the fragile conditions of the Turkish financial and asset markets, and denied both the monetary (the Central Bank) and the fiscal (the Treasury) authorities' utilization of their traditional tools of austerity, rendering them powerless against the speculative forces of the markets, all in the name of good governance.

\section{THE FINANCIAL AND FISCAL FRAGILITY OF THE TURKISH ECONOMY}

We tabulate the so-called fragility indicators of the Turkish economy in a longer time span in Table 1. As seen in Table 1, the Turkish economy rested on a quite shallow and unbalanced financial base throughout the whole 1990s. In this context, one of the important elements of the culminating process of external fragility can be measured by the ratio of short-term foreign debt to Central Bank's international reserves. This ratio is interpreted as one of the crucial leading indicators of external fragility and has recently been called as the most robust predictor of a currency crisis in Rodrik and Velasco (1999, pp. 60-1). It is alarming to note that in Turkey this particular ratio has never fallen below the $100 \%$ mark since the opening of capital account in 1989. Thus, the Turkish financial system has been operating constantly under the 'danger zone' for the past 12 years.

What is crucial to note in Table 1 is that the disinflation program actually deepened the fragility as signaled in this indicator. Let alone turning this path to a favorable trend, the 2000 program which aimed at disinflation (and stabilization) caused an increase of external fragility with a rise of this indicator to $112 \%$ in June, and to $145 \%$ by December 2000 (Yeldan, 2002). This level was the highest score since 1993, just before the 1994 financial crisis. Yet, the authors of the Letter of Intent ${ }^{12}$ envisaged that possible increases in central bank reserves would be able to match the increase in outstanding short-term foreign debt, and that Turkey would be able to remain sound externally. However, the external accounts deteriorated in 
CIZRE AND YELDAN: THE TURKISH ENCOUNTER

Table 1 Financial and fiscal fragility in the Turkish economy

\begin{tabular}{|c|c|c|c|c|c|c|c|c|}
\hline & 1995 & 1996 & 1997 & 1998 & 1999 & 2000 & 2001 & 2002 \\
\hline \multicolumn{9}{|l|}{ As ratios to the GNP (\%) } \\
\hline Current account balance & -1.4 & -1.3 & -1.4 & 1.0 & -0.7 & -4.8 & 1.4 & -1.0 \\
\hline Foreign debt stock & 42.8 & 46.2 & 47.8 & 47.2 & 55.7 & 59.1 & 76.9 & 73.1 \\
\hline Domestic debt stock & 14.6 & 18.8 & 21.4 & 22.5 & 29.3 & 28.7 & 69.2 & 54.0 \\
\hline Budget balance & -4.0 & -8.3 & -7.6 & -7.0 & -11.6 & $-11.6^{a}$ & $-18.2^{a}$ & -14.3 \\
\hline $\begin{array}{l}\text { Non-interest } \\
\text { (primary) budget }\end{array}$ & 3.4 & 1.7 & 0.1 & 4.7 & 2.1 & 5.7 & 6.7 & 4.7 \\
\hline $\begin{array}{l}\text { Public sector } \\
\text { borrowing req. }\end{array}$ & 5.2 & 8.8 & 7.6 & 9.2 & 15.1 & 11.9 & 16.5 & 12.5 \\
\hline \multicolumn{9}{|l|}{ Fragility indicators } \\
\hline $\begin{array}{l}\text { Short-term foreign } \\
\text { debt/CB international } \\
\text { reserves }(\%)\end{array}$ & 128.7 & 104.2 & 95.1 & 105.4 & 98.9 & 127.6 & 85.9 & 56.5 \\
\hline $\begin{array}{l}\text { M2Y /CB international } \\
\text { reserves }(\%)\end{array}$ & 354.0 & 314.1 & 287.8 & 321.8 & 329.4 & 381.4 & 380.6 & 174.3 \\
\hline Currency substitution $^{b}$ & 54.8 & 50.9 & 48.6 & 45.1 & 45.2 & 44.1 & 56.0 & 56.2 \\
\hline $\begin{array}{l}\text { Interest paym. } \\
\text { on domestic debt/total } \\
\text { tax revenues }(\%)\end{array}$ & 43.9 & 59.2 & 41.7 & 61.0 & 66.4 & 63.7 & 103.4 & 87.0 \\
\hline $\begin{array}{l}\text { Interest paym. } \\
\text { on domestic debt/net } \\
\text { new dom. borrowing }(\%)\end{array}$ & 93.7 & 83.1 & 63.5 & 97.9 & 87.5 & 137.8 & 47.2 & 187.2 \\
\hline $\begin{array}{l}\text { Net new domestic } \\
\text { borrowing/domestic } \\
\text { debt stock }(\%)\end{array}$ & 52.4 & 57.8 & 52.4 & 49.5 & 49.3 & 37.1 & 70.2 & 18.5 \\
\hline
\end{tabular}

${ }^{a}$ Exclusive of transfers from the $\mathrm{CB}$, interest revenues and privatization receipts.

${ }^{b}$ (Rate of Dollarization): Ratio of foreign exchange deposits to total deposits of residents. Sources: SPO Main Economic Indicators; Undersecreteriat of Treasury, Main Economic Indicators.

spite of the $\$ 4$ billions reserve assistance obtained from the IMF in late November 2000. The generous external support did not suffice to generate stability in the domestic macro environment, and the Turkish asset markets drifted to the worst economic crisis in its history in February 2001.

Table 1 underscores one of the most striking indicators of the Ponzifinance attitudes of the Turkish fiscal authorities: the ratio of the net new domestic borrowings to the domestic debt stock. Since 1995 - with the exception of 2000 - the Turkish Treasury has been engaged in net new borrowing amounting to almost half of its already incurred stock of debt. The net new domestic borrowing of 2001 added to the existing debt stock as much as $70 \%$. The real meaning of the objective of 'debt turn-over' is thus very clear. The central budget is being utilized mainly as an instrument of transferring real income to the rentier classes rather than regulating domestic savings and investment targets. In other words, the budget in Turkey has now turned into an instrument of transferring real resources to the financial sector, rather than financing social infrastructure and economic growth. 


\section{REVIEW OF INTERNATIONAL POLITICAL ECONOMY}

In terms of the causes of the February 2001 crisis, for the political mismanagement school, the crisis is the result of crony capitalism, which is a deviation from market economy. In contrast, we regard such cronyism as the unavoidable outcome of the changing nature of global networks of finance. In fact, the main source of the contested fragility of the Turkish financial sector can be traced back to the 1989 decision to eliminate all the regulations on the capital account. This decision liberalized all external financial transactions of the Turkish economy vis-à-vis the rest of the world and led the domestic asset markets to be dependent on the short-term, speculative movements of foreign capital flows.

\section{POLITICS IN THE POST-CRISIS ERA}

Three principal features define the ways in which the Turkish political structure and dynamics connect with the structural adjustment processes under post-crisis conditions. First, the economic crisis served to reinforce the political status quo rather than change it. Second, the crisis precipitated a regressive trend in politics. While the political eminence of the civil-military bureaucracy rose, the relevance and weight of representative institutions receded. Third, given heavy loan conditionality, the economic and political decision-making process was delegated out to a level where international financial organizations achieved ultimate veto power. In conclusion, we take each of these issues in turn.

\section{The politics of Turkish inertia - in comparative perspective}

Regarding the first point, it is necessary to note that perhaps as significant as the economic crash itself was the lack of an imaginative leap of statecraft that took place after February 2001 when no attempt was made to modify the extant political structure to cope with the public's mounting discontent. The economic slump provided the context for a growing awareness of limitations of the prevailing political system as well as of the need for a radical transformation. However, despite the ongoing clichés of reform and liberalization, politics in Turkey sought refuge, if anything, in the status quo. The three-party coalition government, which oversaw the post-2001 crisis management, epitomized this inertia. It did not owe its longevity to its political ingenuity, or empathy with the hopes and fears of the masses. It stayed put because in order to provide confidence to the markets, government stability was regarded as crucial at a time when the country was going through difficult times. Therefore, it became a government by default, coexisting relatively peacefully with both a highly centralized military and civil bureaucracy and a powerful president. The serious vacuum in political authority was complemented by the absence of any viable opposition. The coalition sustained itself in office more by the 


\section{CIZRE AND YELDAN: THE TURKISH ENCOUNTER}

absence of serious challenges to its policies than by its own muscle power. This situation was also a result of the policies of dominant domestic and international actors who preferred the status quo to the uncertainties and ambiguities of 'change' for fear that it might upset political balances that may lead to a worsening of economic conditions.

The political consequences of such economic crises are played-out through regime characteristics and structures. Since Turkey has a unitary and parliamentary system of state marked by a strong party tradition, erosion of the governing capacity of the institutions was observable on the parliamentary, governmental, and political party levels. In contrast, in countries that have a federal and presidential systems of state like Argentina, which is still reeling from the devastating effects of its financial collapse in December 2001, it was the political power of the president and the federal institutions which disintegrated while that of the Governors and institutions of the provinces rose. That the IMF itself resorted to direct negotiations with the Governors attests to the fragmentation of power both before and after the crisis (Escude, 2002, p. 459). Power wielded in today's Argentina is increasingly province-based with relatively rich provinces having an advantage of their own.

The January 1999 financial crisis of Brazil, another federal state, was not only triggered by one of the federal states declaring moratorium on payment of state's debt to the federal government, but as the crisis unfolded, the power of the president and the congress declined and the fiscal and administrative powers of the Governors went up (Flynn, 1999, p. 308). The president and his team also exhibited clear signs of 'political inertia' before and after the crisis, in terms of not giving sufficient political priority to driving through the congress the reforms which were needed, most notably the measures for social reform in a country with one of the worst patterns of wealth distribution in the world.

Judging by these similar episodes, it is relatively unsurprising then that an important aspect of the politics of this crisis was the Turkish government's increasing emphasis on conservative policies. As distributional stress mounted, the bureaucracy tried to create some sense of security and certainty by moving to a discourse that made no promises of change although the system had already been rendered obsolete by the emergence of the crisis. ${ }^{13}$ In the aftermath of the February 2001 collapse, new political actors did not supplant the existing political parties and their leaders, and the structures that sustained them were not subject to critical reevaluation and revision. That inertia, in terms of the personalities involved and the structural make-up of Turkish politics supported the tendency to see the political realm as merely a conduit for passing stringent marketization reforms. As neo-liberalism has become the unquestioned orthodoxy, the leading segments of the business, intellectual, party political and bureaucratic communities automatically presumed that the socialist, social 


\section{REVIEW OF INTERNATIONAL POLITICAL ECONOMY}

democratic, and populist alternatives were implausible. Public discussion of the program was framed in the technical language of how the nation would be adjusted to the discipline of monetary and fiscal imperatives. The dominant mode of political imagination became technical know how as technocrats replaced the politicians.

This anti-political mindset was particularly apparent with regard to the expansion of the autonomy of civil and military establishment. The political autonomy of the Turkish Armed Forces (TAF) is a historical reality according to which it has maintained a privileged position as the guardian of the foundational ideology of the Republic (Cizre-Sakallioğlu, 1997). The last crisis not only reinforced this trend but also reaffirmed the military's long-held conviction that Turkey's political cadres are incompetent in the sense that they have failed to instill the fundamental priority of secularism over political Islam, economic discipline over populism, and unity over cultural and social pluralism.

\section{The rise of bureaucracy and fall of representative politics}

A further aspect of the post-crisis politics that the structural adjustment plan generated was the ultimate demise of representative politics based on a mandate. In Turkey, one manifestation of this trend came in the 1980s with the former Prime Minister, Turgut Ozal's promotion of the model of the political entrepreneur, who, as an elected politician either appropriates an existing issue or creates a new policy issue and builds her/his career on its promotion (Cizre 2002a, 2002b). This strategy suffered a setback in the 1990 s when the issues entrepreneurs could promote tended to converge because of the further erosion of the boundaries between the left and the right. Hence, they all tended to agree on a shift from public to private enterprise, from insulation to integration into the world capitalist market, from import-substitution industrialization to an export-led development. Terms like reform and liberalization were used by nearly all political persuasions to indicate that all economies operate according to the same laws. ${ }^{14}$

With or without political entrepreneurs, however, representation in Turkey can no longer be said to correspond to a power generating and distributing process. Policies that define the winners and losers, and the re-construction of the state-economy and state-society relations do not depend on the formation of a public consensus or even the retrospective acquisition of public backing. On the contrary, what matters most is not that politics should deliver the particular policies required and endorsed by the voters at elections, but that they deliver 'effective' policies regardless of the electoral premises. Likewise, leaders believe that they should be able to change their policy plans at a moment's notice, not according to publicly debated and accepted issues, but as determined by their entrepreneurial acumen. 


\section{CIZRE AND YELDAN: THE TURKISH ENCOUNTER}

That neoliberalism raised the profile of political entrepreneurs is part of a global process of redefinition of politics and collective action in many democracies. Speaking of the future matrix of democracy in Latin America, Garreton diagnoses the central trend in terms very similar to that of Turkey's:

'... concrete political projects, politics and policies... make sense if they are capable of giving meaning to and improving the quality of personal and social life. That, in present circumstances depends less on their content ... than on the capability of the individual' (Garreton, 2001, p. 241)

In part, this is owing to the fact that as the grip of one single ideology and meaning in a nation-state loosened, and the socioeconomic transformation under structural adjustment policies weakened the material bases and spaces of social action, those political actors that have emerged have lacked the confidence backed by a publicly validated ideology and they have instead adopted defensive/efficiency issues and ideas.

The development of these politics highlights the detachment of ideas from the material circumstances in which people live. Although economic liberalization has failed to better the real life situation of workers, peasant families and small-scale independent business, it has remained the unquestioned model. Moreover, the neo-liberal conception of the market conveniently forecloses a full critique of the interests it serves. This is the paradox, not only of the Turkish nation, but also of those other countries and continents where neo-liberal model is implemented. The predominant everyday experience of the great majority of people runs counter to the captivation of the public mind by the laissez faire model. Once the life experience of the citizenry is disconnected from the world of ideas, the potential for political backlash by the losers against the system is undermined. Forrest D. Colburn draws attention to the same phenomenon in Latin America where 'public dissatisfaction is not directed at the economic model of the day, unfettered markets. Instead, public disenchantment is focused on corruption and ineptitude in governing ... election results also do not demonstrate public rejection of the economic model' (Colburn, 2002, p. 36). He then connects this development with 'common fatalism about politics, as if all outcomes are foreordained' (Colburn, 2002, p. 38), which, can be interpreted as a product of lack of ideas and conflicting paradigms on how to organize state, politics and society.

\section{Politics of loan conditionalities}

The most important way for the IFOs to prompt economic reform is through stringent loan conditionality. In the past, the populist base of politics and nationalist sensitivities in such states rendered loan conditionality 
unattractive to the Turkish political class. However, the extreme crisis-situation of the economy and polity paved the way for such conditionalities. $^{15}$

Conditionality here refers to international policies and incentives that involve the promotion of some minimum requisites and threshold conditions below which defined forms of international support will purportedly be withheld, and above which they can be supplied' (Whitehead, 1996, p. 257). In the literature on conditionality a distinction is made between three types of conditionality (Whitehead, 1996). Whereas the first set of conditionality policies aims at restraining certain undesirable forms of conduct like the violation of human rights, the second set targets to improve measurable types of performance in the administrative and economic realm. The objective of the third group of incentives, on the other hand, is 'to promote the much more complex and imprecise processes' of enhanced participation, increased political competition, and the quality of democratic rule (Whitehead, 1996, p. 262).

Unfortunately, conditions designed to promote democratic practices are much more limited than conditions designed to fulfill the other two objectives. The difficulty arises from various factors, for example, democracy promotion is mediated as much through the work of the local players as through transnational players and cleavage patterns and political loyalties. More important however, the eventual prospects of democratic reform in a country transcend the constitutional and legislative changes and include social, cultural, and psychic ambits. There is not, however, a necessary consensus on just how wide and how deep the less invisible changes in the foreground should be. In addition, the growing role of the IFOs in pressing for reform in the democracy-oriented climate of the post-Cold War era, can meet entrenched resistance not just from those who gain from partaking in the public sector spoils but also from sectors of bureaucracy, which consider themselves as the ideological guardians of the state. The main objective for this sector is to maintain its strategic position as the chief interlocutor in politics.

It is not surprising then that the IMF's political agenda and foreign policy-based concerns are centered on providing international support to Turkey, a country that is a strong ally of the western bloc in a highly sensitive region. The September 11th attacks have only served to reinforce the geopolitical significance of Turkey to the United States. ${ }^{16}$ Alternatively, after gaining candidate country status at the December 1999 Helsinki Summit of the European Council, the European Union prescribed a package of political preconditions that must be fulfilled if Turkey is to gain entry into the European fold successfully. This pressure continues even though December 2002 Copenhagen Summit set December 2004 as the date to review Turkey's progress on democratization to decide when to start accession negotiations. In this regard, a comparison of the Turkish and 


\section{CIZRE AND YELDAN: THE TURKISH ENCOUNTER}

Argentinean cases with regard to their IMF links offers a stark contrast. After years of support for Argentina during the Cold War, as the political importance of the country was deemed to have declined in the post Cold War era, the IMF reversed its course in late 2001 and refused Argentina's request for '... a waiver on its fiscal targets to enable the disbursal of $\$ 1.2$ billion from one last loan in August 2001' (Starr, 2003, p. 70). The country went into default and financial collapse in December 2001.

In contrast, in Turkey, loan conditionality is used as a tool to promote economic re-structuring without altering the basic power structure in a way that would threaten Ankara's position as a close partner of the EuroAtlantic Community. What it seeks to do is to set in motion the forces of the free-market by reducing the economic resources flowing through the public sector. As a result, the scope of political patronage available to the power wielders in the Turkish political system is curtailed. This reflects an understanding of politics as an epiphenomenon of the economic dynamics, which can only emerge when Ankara's economic patronage networks are dried up by a severe reduction for money running through the public sector.

\section{CONCLUSIONS}

In this article, we have argued that the February 2001 economic and political crisis was not the result of a set of unfortunate mishaps or administrative errors unique to Turkey, but was the result of a series of pressures emanating from the process of integration with the global capital markets. It is true that in Turkey there is a heightened awareness and perhaps a firm consensus that economic paralysis was a product of political ineptness and corruption. According to this view, the regulatory policies of the state have both led to corrupt public procurement policies and to shady dealings and contracts in the state enterprises and banks. More importantly, the perception that Turkey is passing through a critical juncture of history with the security, well-being, and integrity of the individuals being put at substantial serious risk, has given rise to a fresh willingness for wide-reaching reform.

However, the public's enthusiasm for a departure from corruption, cronyism, and unconstrained greed should not be taken as signifying unequivocal support for the shape and scope of the reform policies envisaged by Turkey's ongoing structural adjustment program. This program is incapable of rallying a conscious public demand for substantive change for two basic reasons. First, it lacks democratic legitimacy. Second, it cannot overcome the obstacles posed by the very nature of the program insofar as it fails to address the basic human needs. The absence of a democratic dimension in the structural adjustment program means there is a lack of a meaningful and critical public debate that goes beyond 


\section{REVIEW OF INTERNATIONAL POLITICAL ECONOMY}

scientific-sounding technicalities and provides genuine alternatives for consideration. As the program depends heavily on disciplined behavior, restrained expectations, and limited demands by the population, a democratic public space would be highly inimical to the achievement of its fundamental objectives.

Given these conclusions, it is clear that the ongoing stabilization program officially outlined in the Transition to Strong Economy Program (May 2001) and the series of Letter of Intent given to the IMF, pursue a rather dogmatic development model. This model is built on false assumptions and contradictory policies. Its perspective on international capital flows, for instance, is that in a market economy, international capital mobility helps allocate savings and investments more efficiently and diversifies investment opportunities and risks. ${ }^{17}$ The model ignores the fact that currency speculators can supplant political decision makers, and that there are no clear indications that liberalization of international capital flows can deliver sustainable growth and better equity. Furthermore, in this model, what is really meant by the concept of stabilization is to establish an exchange rate system free from the devaluation risk, and to maintain high real returns in the national financial markets to attract foreign capital.

Under this structure, the central banks are set to be autonomous and their means of intervention in the economy are restricted, so that they would not undertake any role apart from maintaining price stabilization. Fiscal policies are to be directly focused on the objective of maintaining a budget with a primary surplus. As result of these policies, the boundaries of the public space are restricted and traditional economic and social infrastructural facilities of the public sector are left to the strategic interest of foreign capital at the cost of extraordinary cuts in public spending and investments. In other words, the adjustment program simply opens the way for Turkey's resources to be siphoned-off by international speculators rather than orienting the Turkish economy on a sustainable and equitable growth path.

\section{NOTES}

1 See Akyüz and Boratav (2003); Boratav, Yeldan and Kose (2002); Yeldan (2002); Ertuğrul and Selcuk (2001, 2002); Metin-Özcan, Voyvoda and Yeldan (2001); Cizre-Sakallığlu and Yeldan (2000); Kepenek and Yentürk (2000); Uygur (1996); and Ekinci (1998) for a thorough overview of the post-1990 Turkish macroeconomic history. Bicer and Yeldan (2003); Balkan and Yeldan (2002); Gürkaynak (2000); Öniş and Aysan (2000); and Yentürk (1999) provide similar analyses based on the effects of international speculative financial capital flows on the Turkish economy. Yeldan $(1995,1998)$, in turn, discusses the characteristics of the post-1990 Turkish macro adjustments in terms of creation and absorption of the economic surplus, and provide a quantitative analysis on the strategic role played by the state apparatus. 


\section{CIZRE AND YELDAN: THE TURKISH ENCOUNTER}

2 On the 'official' evaluation of the 2001 crisis, see Transition to Strong Economy Program, Undersecretariat of Treasury, Ankara. (www.treasury.gov.tr)

3 See, for example, Alper and Yilmaz, 2003; Ertugrul and Selcuk (2001, 2002).

4 This is a long-held conviction prevalent not only among policy-makers but also journalists, politicians of all spectrum, intellectuals and theorists. For a succinct summary of this argument in the 1990s, see Cizre-Sakallioglu and Yeldan (2000).

5 The best evidence comes from the prolific research publications of powerful TUSIAD, the Turkish acronym for Turkish Industrialists and Businessmen's Organization and TESEV, Turkish Foundation for Economic and Social Research, the websites of which can be used to obtain the publications. The respective addresses are http://www.tusiad.org.tr and http:/ / www.tesev.org.tr

6 Interview with Kemal Derviş by Leyla Boulton and Martin Wolf, 'Winning Turkey's Trust', Financial Times, 14 May 2001.

7 For a succinct overview of the arguments including this particular perspective on the crisis see Ziya Önis, 'Domestic Politics versus Global Dynamics: Towards a Political Economy of the 2000 and 2001 Financial crisis in Turkey', in Önis and Rubin (2003).

8 A detailed account of corruption in the private sector including the banking and media groups see Seymen (2001), Şener (2001) and Adaman, et al. (2003).

9 See Boratav, Yeldan and Kose (2002); Yeldan $(1995,1998)$ and Somel $(2003)$ for an overview of the recent Turkish economic history emphasizing the nature of class conflict and the role of the state in creation and extraction of the economic surplus.

10 Lecture by Kemal Derviș, Distinguished Lecture Series, European University Institute, Robert Schuman Centre for Advanced Studies, 1 June 2001, p. 16.

11 Elements of this vicious cycle are well known and are studied extensively in the literature. See, for example, Diaz-Alejandro (1985); Velasco (1987); Dornbusch, Goldfajn and Valdés (1995); and Adelman and Yeldan (2000a).

12 Letter of Intent, dated 9 December 1999, signed by Gazi Ercel (the governor of the TR Central Bank and Recep Onal (Minister of State).

13 This mode of managing crises has antecedents in Turkey. When the economy collapsed in January 1994, to cope with the corrosive effects of the distributional crisis which ensued, Tansu Çiller, the then-prime minister took an even more conservative political turn by deploying a rhetorical strategy that focused on nationalism, religion, cultural values and embracing an anti-liberal position with regard to the individual rights, civil society and democratization (Cizre, 2002a).

14 For an historical understanding of the issue of 'convergence' of almost all political platforms on neo-liberal oriented values and policies see my own two works: Cizre-Sakallıglu (1996) and Cizre (2002a).

15 The IMF's conditions were based on structural reform, first on a pegged, and then on the free floating of the Lira, fiscal tightening in the public sector through spending cuts, privatization, a more autonomous central bank and the overhaul of the banking sector.

16 President Bush called the then Prime Minister Bülent Ecevit only two days after the outbreak of the crisis to give his strongest support to the economic reforms. Again, on 14 December 2001, President Bush expressed his administration's positive backing by personally asking the Turkish ambassador in Washington about the economic situation in Turkey and wishing the country well in its problems. Is it worth pointing out that this runs contrary to the initial policy position of the newly elected Bush administration? The 


\section{REVIEW OF INTERNATIONAL POLITICAL ECONOMY}

treasury secretary Patrick $\mathrm{O}^{\prime} \mathrm{Neill}$, in outlining the administrations then isolationist position, made it very clear that any country that got itself into trouble would not be bailed out. Turkey was subsequently bailed out; Argentina was not.

17 This claim, referred to as the McKinnon-Shaw hypothesis, provides the theoretical backbone of the neo-liberal ideology advocating financial de-regulation and liberalization. See, McKinnon (1973); and Shaw (1973). For a review on the history of the rise of neoliberal paradigm as the hegemonic ideology in shaping macroeconomic policy, see George (2000).

\section{REFERENCES}

Adaman, F. et al. (2003) İş Dünyası Açısından Yolsuzluğun Nedenleri ve Önlenmesine İlişkin Öneriler (The Causes of Corruption Suggested Measures against It from the Perspective of Turkey's Business Community), Istanbul: Report by TESEV Publications.

Adelman, I. (2000) 'Redrafting the Architecture of the Global Financial SystemEditor's Introduction', World Development, 28(6): 1053-60.

Adelman, I. and Yeldan, E. (2000a) 'The Minimal Conditions for a Financial Crisis: A multi-regional Inter-temporal CGE Model of the Asian crisis', World Development, 28(6): 1087-100.

Adelman, I. and Yeldan, E. (2000b) 'Is This the End of Economic Development?', Structural Change and Economic Dynamics, 11: 95-109.

Akyüz, Y. and Boratav, K. (2003) 'The Making of the Turkish Crisis', World Development, 31(9): 1549-66.

Alper, E. and Yilmaz, K. (2003) 'Domestic Needs for Finance and Exchange Rate Regime Choice in Developing Countries, with Special Reference to the Turkish Experience', Turkish Studies, 4(2): 67-91.

Baker, D., Epstein, G. and Pollin, R. (1998) Globalization and Progressive Economic Policy, London: Cambridge University Press.

Balkan, E. and Yeldan, E. (2002) 'Peripheral Development under Financial Liberalization: The Turkish Experience', in N. Balkan (ed.) The Ravages of NeoLiberalism: Economy, Society and Gender in Turkey, New York: Nova Science Pub.

Bicer, G. and Yeldan, E. (2003) 'Patterns of Financial Capital Flows and Accumulation in the Post-1990 Turkish Economy', Canadian Journal of Development Economics, 24(2): 249-66.

Boratav, K., Yeldan, E. and Köse, A. (2002) 'Globalization, Distribution and Social Policy: Turkey: 1980-1998', in L. Taylor (ed.) External Liberalization and Social Policy, London and New York: Oxford University Press.

Boratav, K. and Yeldan, E. (2002) 'Turkey, 1980-2000: Financial liberalization, Macroeconomic (in)stability, and Patterns of Distribution', CEPA and The New School for Social Research, mimeo, Available at http://www.bilkent. edu.tr/ yeldane/crisis.htm.

Bourdieu, P. (1998) 'The Essence of Neoliberalism', Le Monde Diplometique, December.

Cizre, Ü. (2002a) 'From Ruler to Pariah: The Life and Times of the True Path Party', Turkish Studies, 3(1): 96-9.

Cizre, Ü. (2002b) 'Tansu Çiller: Lusting for power and undermining democracy', in M. Heper and S. Sayarı (eds) Political Leaders and Democracy in Turkey, Lanham, Boulder, New York, Oxford: Lexington Books, 199-216. 


\section{CIZRE AND YELDAN: THE TURKISH ENCOUNTER}

Cizre-Sakallığlu, Ü. (1996) 'Liberalism, Democracy and the Turkish Center-Right: the Identity Crisis of the True Path Party', Middle Eastern Studies, 32(2): 142-61.

Cizre-Sakallığlu, Ü. (1997) 'The Anatomy of the Turkish Military's Autonomy', Comparative Politics, 29(2): 151-66.

Cizre-Sakallığlu, Ü. and Yeldan, E. (2000) 'Politics, Society and Financial Liberalization: Turkey in the 1990s', Development and Change, 31(1): 481-508.

Colburn, D. Forrest (2002) Latin America at the End of Politics, New Jersey: Princeton University Press.

Diaz-Alejandro, C. F. (1985) 'Good-bye financial repression, hello financial crash', Journal of Development Economics, 19: 1-24.

Dornbsuch, R., Goldfajn, I. and Valdés, R. (1995) 'Currency crises and collapses', Brookings Articles on Economic Activity, 2: 219-70.

Ekinci, N. (1998) 'Türkiye ekonomisinde gelimenin dinamikleri ve kriz', Toplum ve Bilim, 77: 7-27.

Ertuğrul, A. and Selcuk, F. (2001) 'A brief history of the Turkish economy, 19902000', Russian and East European Finance and Trade, 37: 6-28.

Ertuğrul A. and Selcuk, F. (2002) 'Turkish Economy: 1980-2001' in A. Kibritcioglu, L. Rittenberg and F. Selcuk, Inflation and Disinflation in Turkey, Aldershot: Ashgate Pub. Co.

Escuda, C. (2002) 'Argentina: a parasite state on the verge of disintegration', Cambridge Review of International Affairs, 15(3): 453-67.

Evans, P. (1997) 'The eclipse of the state, reflections on stateness in an era of globalization', World Politics, 50: 62-87.

George, S. (2000) 'A Short History of Neoliberalism: Twenty Years of Elite Economics and Emerging Opportunities for Structural Change', in W. Bello, N. Bullard, and K. Malhotra (eds) Global Finance: New Thinking on Regulating Speculative Capital Markets, London: Zed Books, ch. 2, 27-35.

Flynn, P. (1999) 'Brazil: the politics of crisis', Third World Quarterly, 20(2): 287-316.

Garreton, M. A. (2001) 'The new socio-political matrix', in M. A. Garreton and E. Newman (eds) Democracy in Latin America, Reconstructing Political Society, Tokyo, New York, Paris: United Nations University Press.

Grabel, Ilene (1995) 'Speculation-Led Economic Development: A Post-Keynesian Interpretation of Financial Liberalization Programmes in The Third World', International Review of Applied Economics, 9(2): 127-249.

Gürkaynak, R. (2000) 'Real appreciations, capital flows, and twin crises', article presented at The IV. METU International Conference in Economics, 13-16 September, Ankara.

Kepenek, Y. and Yentürk, N. (2000) Türkiye Ekonomisi, Istanbul: Remzi Yayınevi.

McKinnon, R. (1973) Money and Capital in Economic Development, Washington DC: Brookings Institution.

Metin-Özcan, K., Voyvoda, E. and Yeldan, E. (2001) ‘Dynamics of macroeconomic adjustment in a globalized developing economy: growth, accumulation and distribution, Turkey 1969-1998', Canadian Journal of Development Studies, 22(1): 217-53.

Öniş, Z. and Aysan, A. (2000) 'Neoliberal globalization, the nation-state and financial crises in the semi-periphery: A comparative analysis', Third World Quarterly, 29(1): 119-39.

Öniş, Z. and Rubin B. (2003) The Turkish Economy in Crisis, London and Portland, OR: Frank Cass \& Co. Ltd.

Özatay, F. and Sak, G., (2002) 'The 2000-2001 Financial Crisis in Turkey', article presented at the Brookings Trade Forum 2002: Currency Crises, Washington DC, May 2002 (mimeo.) 


\section{REVIEW OF INTERNATIONAL POLITICAL ECONOMY}

Pettifor, A. (2003) Real World Economic Outlook: The Legacy of Globalization Debt and Deflation, New York: Palgrave Macmillan.

Rodrik, D. and Velasco, A. (1999) 'Short-term Capital Flows', Proceedings of the Annual World Bank Conference on Development Economics, Washington DC: The World Bank, 59-90.

Sachs, J. (1997) 'Personal View', Financial Times, 30 July.

Seymen, S. (2001) Amiral Battı: Sabah Grubunun Öyküsü (The Admiral Has Sunk: the Story of the Sabah Group), Istanbul: Metis Yayınları.

Shaw, E. S. (1973) Financial Deepening in Economic Development, New York: Oxford University Press.

Starr, P. (2003) 'Argentina: Anatomy of a Crisis Foretold', Current History, February: 65-71.

Somel, C. (2003) 'Estimating the Surplus in the Periphery: An Application to Turkey', Cambridge Journal of Economics, 27(6): 919-33.

Strange, Susan (1986) Casino Capitalism, Oxford: Basil Blackwell.

Şener, N. (2001) Tepeden Tırnağa Yolsuzluk (Corruption from Top Down), Istanbul: Metis Yayınları.

Uygur, E. (1996) 'Export Policies and Export Performance: The case of Turkey', mimeo.

Velasco, A. (1987) 'Financial Crises and Balance of Payments Crises: A Simple Model of Southern Cone experience', Journal of Development Economics, 27(1-2): 263-83.

Whitehead, L. (1996) 'Concerning International Support for Democracy in the South' in R. Luckham and G. White (eds) Democratization in the South: the Jagged Wave, New York: Manchester University Press.

Yalman, G. (2002) 'Tarihsel Bir Perspektiften Türkiyede Devlet ve Burjuvazi: Rölativist bir Paradigma mi Hegemonya Stratejisi mi?'(State and the Bourgeoisie in Turkey from a Historical Perspective: A Relativist Paradigm or a Strategy of Hegemony?) Praxis, 5(Winter): 7-23.

Yeldan, E. (1998) 'On Structural Sources of the 1994 Turkish Crisis: A CGE Modeling Analysis', The International Review of Applied Economics, 12(3): 397-414.

Yeldan, E. (1995) 'Surplus Creation and Extraction under Structural Adjustment: Turkey, 1980-1992', Review of Radical Political Economics, 27(2): 38-72.

Yeldan, E. (2002) 'On the IMF-directed disinflation program in Turkey: A program for stabilization and austerity or a recipe for impoverishment and financial chaos?', in N. Balkan and S. Savran (eds) The Ravages of Neo-Liberalism: Economy, Society and Gender in Turkey, New York: Nova Science Pub.

Yentürk, N. (1999) 'Short-term capital inflows and their impact on macroeconomic structure: Turkey in the 1990s', The Developing Economies, 37(1): 89-113. 